\title{
EFFICACY OF AZITHROMYCIN ON EXPERIMENTAL TOXOPLASMOSIS INFECTED MICE
}

\section{By}

MONA E. NASR ${ }^{1}$, ATEF H. ABD EL HAMID ${ }^{1}$, NAGWA S. M. ALY ${ }^{1}$, GHADA H. OMAR ${ }^{1 *}$, ASHRAF M. A. BARAKAT ${ }^{2}$, KAWKAB A. AHMED ${ }^{3}$, SAFAA H. YOUSSIF ${ }^{1}$ and GEHAN A. RASHED ${ }^{1}$

Department of Parasitology ${ }^{1}$, Faculty of Medicine, Benha University, and Department of Zoonotic Diseases ${ }^{2}$, National Research Centre, Cairo 12622, and Department of Pathology ${ }^{3}$, Faculty of Veterinary Medicine, Cairo University, Giza, 12211, Egypt

( ${ }^{\star}$ Correspondence: ghadahelmy84@yahoo.com)

\section{Abstract}

Toxoplasma gondii is an opportunistic protozoan that causes a devastating disease in immunocompromised individuals and congenitally infected neonates or children. This study evaluated the efficacy of early Azithromycin treatment of Toxoplasma gondii infected mice with cystogenic Me 49 non-virulent strain. Fifty laboratory-bred female Swiss albino mice were divided into 5 groups: G1: Non-Infected, G2: Infected non-treated, G3: Infected and treated by Azithromycin 200 $\mathrm{mg} / \mathrm{kg}$ at $4^{\text {th }}$ day post-infection for 3 days, G4: Infected and treated by Azithromycin $200 \mathrm{mg} / \mathrm{kg}$ at $4^{\text {th }}$ day post-infection for 10 days \& G5: Infected and treated by Spiramycin $200 \mathrm{mg} \backslash \mathrm{kg}$ at $4^{\text {th }}$ day post-infection for 2 weeks, brain cysts' number, size and histopaholoical changes were assessed after 3 months. Treatment with Azithromycin for 10 days decreased number and size of brain cysts by $70 \%$ \& $40 \%$ respectively without significant difference with Spiramycin treated mice that caused reduction by $74 \%$ \& $50 \%$ respectively. Azithromycin treatment for 3 days caused the least reduction by $51 \%$ \& $21 \%$ respectively and Azithromycin treatment for 10 days decreased the histo-pathological changes in cerebral toxoplasmosis. Azithromycin treatment started at $4^{\text {th }}$ day post-infection was effective than Spiramycin against $T$. gondii infection with a significant effect on cysts count and size and brain pathological changes. Azithromycin treatment for 10 days gave better effect than 3 days.

Keywords: Mice, Azithromycin, Spiramycin, Toxoplasma gondii, Treatment.

\section{Introduction}

Toxoplasmosis is a disease caused by Toxoplasma gondii an obligate intracellular protozoan parasite infecting many hosts, including humans (Hampton, 2015). Toxoplasmosis is categorized into acute and chronic stages. Acute or early stage correlated with the proliferative form (tachyzoite), but tissue cyst predominated during chronic infection, although tachyzoites have been found outside of cysts at this stage (Sullivan and Jeffers, 2012). Studies on T. gondii drug(s) is a complicated task and must be active against both tachyzoites and bradyzoites (Konstantinovic et al, 2019). In-vitro \& in-vivo studies were carried out to reach $\mathrm{LC}_{50}$, a high selectivity index in vitro, prolonged survival of infected in animal models of acute infection and decreased parasite loads in brain and muscle tissues in chronic infection (Mc-Farland et al, 2016). Treatment of cerebral toxoplasmosis was hindered by the less-drug brain penetration to have effective dose (Chew et al, 2012). Combination of sulfadiazine \& pyrimethamine were effective against acute toxoplasmosis (Israelski and Remington, 1993), but was less effective against chronic cerebral one (Faucher et al, 2011). Pyrimethamine and sulfadiazine gave some sideeffects (Castro-Filice et al, 2014).

Azithromycin, a macrolide antibiotic, is a derivative of erythromycin with an anti-Toxoplasma effect (Castro-Filice et al, 2014), used to treat pneumonia, Chlamydia, and protozoa like Entamoeba histolytica, Giardia lamblia (Crouch et al, 1990; Lode et al, 1996), Plasmodium spp. (Srivastava et al, 2012), Cryptosporidium parvum (Giacometti et al, 2000) and Leishmania major (Krolewiecki et al, 2002). In-vitro, human Azithromycin dose neither affected fertility nor the fetus (Briggs et al, 2011).

This study aimed to evaluate the efficacy of early Azithromycin ${ }^{\circledR}$ treatment of acute to 
xoplasmosis in murine with cerebral infection by Me 49 non-virulent strain of T. gondii as compared to Spiramycin ${ }^{\circledR}$.

\section{Materials and Methods}

T. gondii Me 49 non-virulent strain was kindly supplied by Zoonosis Department, National Research Center was regularly maintained by sub-passage in Swiss Albino mice with $0.1 \mathrm{ml}$ of brain homogenate, as $1 \times 10^{2}$ tissue cysts/ml every 8 weeks to develop chronic toxoplasmosis. Brains were grinded with sterile pestle in a clean mortar and diluted to $1 \times 10^{2}$ cysts $/ \mathrm{ml}$ brain cysts suspension (Djurković-Djakovićet al, 2002).

Drugs: 1- Spiramycin tablets (control) 3 MIU (704mg) Spirex were purchased from Medical Union Pharmaceuticals, Egypt. Tablets were crushed and dissolved in distilled water for oral suspension a dose of $200 \mathrm{mg} /$ $\mathrm{kg}$ /day. 2- Azithromycin drug $200 \mathrm{mg} / 5 \mathrm{ml}$ powder for oral suspension Zithromax manufactured by Pfizer Egypt. The drug was dailyprepared as liquid suspension; after sonication, the homogenized suspensions were given orally to mice by stomach tube, in a dose of $200 \mathrm{mg} / \mathrm{kg}$ day. Oral dose was $0.1 \mathrm{ml}$ /mouse (Grujic et al, 2005).

Experimental Design: Fifty clean laboratory-bred female Swiss albino mice, 10 weeks old and 20-25gm were divided into 5 groups of 10 mice in each: G1: Non-Infected, G2: Infected non-treated group, G3: Infected and treated by Azithromycin $200 \mathrm{mg} / \mathrm{kg}$ at $4^{\text {th }}$ day post-infection for 3 days, G4: Infected and treated by Azithromycin $200 \mathrm{mg} / \mathrm{kg}$ at $4^{\text {th }}$ day post-infection for 10 days, G5: Infected and treated by Spiramycin $200 \mathrm{mg} \backslash \mathrm{kg}$ at $4^{\text {th }}$ day post-infection for 2 weeks.

Assessment of anti-Toxoplasma effects: 1Brain cysts number: At the end of 8 weeks, all mice were sacrificed, and brains were dissected out. Each brain was divided into 2 parts, one part for counting the cysts and the second was fixed in $10 \%$ formalin for histopathological studies. They were harvested, rinsed in sterile saline solution, weighed, and $1 \mathrm{ml}$ of sterile saline was added, follo- wed by homogenization (Omni TH-220) for $5 \mathrm{~min}$. A homogenate brain $(0.1 \mathrm{ml})$ was spread on a clean slide, air dried, fixed in methanol, air dried and stained with Giemsa stain (Merck, Germany) for 30-45min., washed with water, dried, and examined microscopically for cysts numbers. The following equation was used: Mean cyst number $=$ cyst count in $100 \mu \mathrm{l} \times 10 \times 2$. 2- Brain cyst size was measured by an ocular \& stage micrometers.

Histopathological examination: Brain specimens were fixed in $10 \%$ neutral buffered formalin,paraffin sections of $5 \mu \mathrm{m}$ thickness, stained with hematoxylin and eosin (H\&E) and microscopically examined.

Statistical analysis: Data were coded, tabulated and analyzed using (ANOVA) procedure and Post hoc test.

\section{Results}

The brain cysts counting (Tab.1) showed that Azithromycin and Spiramycin treated groups caused significant reduction in number as compared to infected non-treated control ones $(\mathrm{P}<0.05)$. (G4) treated by Azithromycin for10 days gave a higher significant reduction in the number as compared with mice treated by Azithromycin for 3 days $(\mathrm{P}<0.05)$. But, mice treated by Azithromycin for 3 days significantly reduced number of brain cyst, still Spiramycin treated mice (G5), showed more reduction ( $\mathrm{P}<0.05)$. (G4) treated by Azithromycin for 10 days gave more or less equal effect as Spiramycin treated ones $(\mathrm{P}>0.05)$.

Brain cysts size (Tab. 2) showed that Azithromycin and Spiramycin treated mice caused a significant reduction in size as compared with control infected non-treated mice except those with mice treated by Azitromycin for 3 days. (G3) did not cause significant reduction in size as compared to mice treated by Azithromycin for 10 days $(\mathrm{P}>0.05)$. Both Azithromycin treated mice showed lower statistical reduction in cyst size as compared with Spiramycin treated mice (G5) $(\mathrm{P}<0.05)$. 
Table 1: Effect of Azithromycin on number of ME49 Toxoplasma gondii strain brain cysts in female Swiss albino mice.

\begin{tabular}{|l|c|c|c|c|c|}
\hline \multicolumn{1}{|c|}{ Groups } & Dose/day & Total dose & \multicolumn{2}{|c|}{ No of Toxoplasma cyst in mice brain } \\
\cline { 4 - 6 } & & & Mean \pm SD & $95 \%$ CI & $\%$ reduction \\
\hline $\begin{array}{l}\text { G3: Infected and treated by } \\
\text { Azithromycin for 3 days. }\end{array}$ & $200 \mathrm{mg} / \mathrm{kg} /$ day & $600 \mathrm{mg} / \mathrm{kg} / \mathrm{day}$ & $260 \pm 43$ & $229-291$ & $51 \%$ \\
\cline { 4 - 6 } $\begin{array}{l}\text { G4: Infected and treated by } \\
\text { Azithromycin 10 days group }\end{array}$ & & $2000 \mathrm{mg} / \mathrm{kg} /$ day & $164 \pm 26$ & $145-183$ & $70 \%$ \\
\hline $\begin{array}{l}\text { G5: Infected and treated by } \\
\text { Spiramycin for 2 weeks. }\end{array}$ & $200 \mathrm{mg} / \mathrm{kg} /$ day & $2800 \mathrm{mg} / \mathrm{kg} /$ day & $138 \pm 46$ & $105-171$ & $74 \%$ \\
\hline G2: Infected non treated group & $\mathrm{N} / \mathrm{D}$ & $\mathrm{N} / \mathrm{D}$ & $526 \pm 40$ & $497-555$ & $\mathrm{~N} / \mathrm{D}$ \\
\hline
\end{tabular}

SD: Standard deviation. CI: convenient interval. N/D: No Data

Table 2: Effect of Azithromycin on size of ME49 Toxoplasma gondii strain brain cyst in female Swiss albino infected mice.

\begin{tabular}{|l|l|l|c|c|c|}
\hline Groups & Dose/day & Total dose & \multicolumn{3}{|c|}{ No of Toxoplasma cyst in mice brain } \\
\cline { 4 - 6 } & & & $\mathrm{M} \pm \mathrm{SD}$ & $95 \%$ CI & $\%$ reduction \\
\hline $\begin{array}{l}\text { G3: Infected and treated by } \\
\text { Azithromycin for 3 days. }\end{array}$ & $200 \mathrm{mg} / \mathrm{kg} / \mathrm{day}$ & $600 \mathrm{mg} / \mathrm{kg} /$ day & $19 \pm 3$ & $16-21$ & $21 \%$ \\
\cline { 4 - 6 } $\begin{array}{l}\text { G4: Infected and treated by } \\
\text { Azithromycin for 10 days. }\end{array}$ & & $2000 \mathrm{mg} / \mathrm{kg} /$ day & $15 \pm 2$ & $15-17$ & $40 \%$ \\
\hline $\begin{array}{l}\text { G5: Infected and treated by } \\
\text { Spiramycin for 2 weeks }\end{array}$ & $200 \mathrm{mg} / \mathrm{kg} / \mathrm{day}$ & $2800 \mathrm{mg} / \mathrm{kg} /$ day & $12 \pm 1$ & $11-13$ & $50 \%$ \\
\hline G2: Infected non treated group & $\mathrm{N} / \mathrm{D}$ & $\mathrm{N} / \mathrm{D}$ & $24 \pm 4$ & $20-27$ & N/D \\
\hline
\end{tabular}

Microscopically brain sections from mice infected with Me 49 non-virulent strain of $T$. gondii showed many histopathological alterations in infected non-treated ones in the form of multiple large Toxoplasma cysts scattered through the brain parenchyma (Fig. 1), multiple focal necrosis associated with severe glia cells infiltration and severe perivascular cuffing with mononuclear inflammatory cells (Fig. 2). Mice treated by Azithromycin for 3days showed histopathological alterations in form of mild meningitis, shrunken, atrophy and severe neurons necrosis (Fig. 3) with neurofibrillary tangles (Fig. 4). Moderate perivascular cuffing with mononuclear cells were noticed (Fig. 5). More improvement was in brain tissues in mice treated by Azithromycin for 10days, as moderate degeneration, necrosis of some neurons and intracellular edema (Fig. 6), mild neuron ophagia of degenerated neurons (Fig.7) and moderate gliosis (Fig. 8) were noticed, but, without meningitis or perivascular cuffing. The brain of mice infected with $T$. gondii and treated with Spiramycin 4 days post infection for 2 weeks mice showed congestion of some blood vessels with perivascular edema and degeneration of neurons (Fig.9).

\section{Discussion}

In the present study, (G4) treated by Azithromycin for 10 days $\left(4^{\text {th }}\right.$ day post infection) with good therapeutic efficacy among mice.
This treatment regimen reduction rate in brain cysts' number was $70 \%$. More or less similar effect was recorded with the matching (G5) treated by Spiramycin (74\%) without significant difference between both drugs. and the least reduction found in mice treated by Azithromycin for 3 days (51\%). This agreed with Derouin et al. (1992) who reported that administration of azithromycin at 300 , 150 , or $75 \mathrm{mg} / \mathrm{kg}$ of body weight per day for 10 days from day +1 post-infection did not prevent $T$. gondii dissemination to the brain.

In the present study, a dose $(200 \mathrm{mg} / \mathrm{kg})$ of Azithromycin administered daily for only 3 days was significant when compared with infected control group but better effect was obtained when used for 10 days, as Azithromycin is protein bound in serum and eliminated slowly due to low serum clearance and extensive distribution in the tissues. Thus, detectable levels of the drug can be found in the urine 7 to 14 days after administration of a single dose. The relatively long half-life, the affinity for tissues, and the slow elimination of azithromycin indicate potential for a once-a-day dosing regimen (Araujo et al, 1988). These results were explained by the fact that Azithromycin have significant intracellular accumulation (Gladue et al, 1989) and the only macrolide causing prolonged inhibitory activity on intracellular tachyzoittes replication (Chamberland et al, 1991). 
Azithromycin was superior to both Roxithromycin and Spiramycin in terms of protecting mice against death from acute toxoplasmosis (Araujo et al, 1991). Synergistic activity of Azithromycin combined with metronidazole against experimental toxoplasmosis infected mice was reported (Al-Jader and Al-Mukhtar, 2010). Azithromycin has a good effect in vitro and more effective to control the trophoblast infection with both 2 Brazilian T. gondii genotypes, TgChBrUD1 or TgChBrUD2 when compared to conventional antibiotics Spiramycin and sulfadiazine/pyrimethamine (Ribeiro et al, 2017). Lopes et al. (2009) found that Azithromycin has high potency than different toxoplasmosis treatment option during pregnancy as it reduced the number of pathogenic cysts in brain, and none was detected in the fetuses eyeballs of infected female mice in contrast with mice treated by a combination of Azithromycin $(300 \mathrm{mg} / \mathrm{kg})$, pyrimethamine $(100$ or $50 \mathrm{mg} / \mathrm{kg}$ ), sulfadiazine (100 or $75 \mathrm{mg} / \mathrm{kg}$ ), and folic acid $(15 \mathrm{mg} / \mathrm{kg})$.

In the present study, Azithromycin treated groups effectively reduced the size of brain cysts by $21 \%$ in mice treated for 3 days and $40 \%$ in mice treated for 10 days in contrast to $50 \%$ in Spiramycin treated mice. This could be due to that Azithromycin is the only macrolide demonstrating prolonged inhibitory activity on replication of intracellular tachyzoites (Chamberland et al, 1991), and killed intra-cystic bradyzoites in vitro 6 days after incubation, and decreased the cysts' size (Huskinson-Mark et al, 1991).

In the present study, the patterns of $T$. gondii cyst growth within the brains of experimentally infected mice differed among the mice groups. The tissue cysts were often spherical with well-defined cyst walls and varied in size, from small cysts with 1 or 2 bradyzoites, to large cysts with more than 50 bradyzoites. These results agreed with others found that Toxoplasma cysts in brain grow uniformly in size up to 2 to 3 months post infection and persist for many months post infection (Melzer et al, 2010).
Araujo et al (1991) found that Spiramycin was effective in acute murine infection, with an inhibitory rather than a curative effect.

In the current study, Spiramycin showed the highest effect in decreasing number and size of brain cysts. This agreed with Grujić et al. (2005) who found that a 3-week course of $100 \mathrm{mg}$ Spiramycin $/ \mathrm{kg} /$ day and a 4-week course of $200 \mathrm{mg} / \mathrm{kg} /$ day in mice infected by cysts of Me49 strain, significantly enhanced protection and markedly reduced brain cyst burdens at 6 months post infection.

In the present study, the brain sections of mice infected with the Me 49 non-virulent $T$. gondii strain showed severe histopathological changes in infected non-treated mice (G2) in the form of multiple large Toxoplasma cysts scattered through the brain parenchyma, multiple focal necrosis associated with severe glia cells infiltration and severe perivascular cuffing with mononuclear inflammatory cells. This agreed with Mahmoud (2007) who found that brain lesions were recognized by peri-vascular cellular infiltration, presence of microglial nodules and necrotic foci. The result also agreed with Hermes et al. (2008) who found that toxoplasmosis infection caused a local degenerative cell loss, parasites within neurons and directly caused death of infected neurons or its atrophy and inflammation contributed by the production of nitric oxide and other toxic oxygen products causing to neighboring neurons death.

The least histopathological lesions were found in Spiramycin treated mice (G5). The most effective Azithromycin was achieved in mice treated for 10 days (G4) that showed mild to moderate neuropathological alterations as neurofibrillary tangles, neuronophagia of degenerated neurons, congestion of cerebral blood vessel and proliferation of glia cells and the worst effect was found in Azithromycin treated mice for 3 days (G3) in form of sever necrosis of neurons, neuronophagia, neurofibrillary tangles, perivascular cuffing with mononuclear cells, meningitis (inflammatory infiltrate in meninges). 
The result agreed with Dumas et al. (1994) who recorded that the histological examination of untreated animals showed inflammatory infiltrates and mean encephalitis score was $2.7 / 3$. The brain lesions were characterized by a perivascular leucocyte infiltration (mainly around intracerebral and meningeal blood vessels), presence of microglial nodules and foci of necrosis. But, in Azithromycin treated mice, histological examination showed less inflammatory infiltration and mean encephalitis score was $0.7 / 3$.

\section{Conclusion}

Azithromycin treatment at $4^{\text {th }}$ day postinfection was effective as Spiramycin against $T$. gondii infection with a significant effect on cysts count and size and improved brain pathological changes. Also, Azithromycin treatment for 10 days gave better effect than 3 days treatment. Further in vivo and in vitro studies are recommended to investigate the Azithromycin efficacy against $T$. gondii on a wider scale, to identify its action as anti- $T$. gondii drug and the standardized human doses.

\section{References}

Al-Jader, ZH, Al-Mukhtar, AM, 2010: Synergistic activity of Azithromycin combined with metronidazole against toxoplasmosis in experimental mice. Iraq. J. Pharm. 9, 1:32-5.

Araujo, FG, Guptill, DR, Remington, JS, 1988: Azithromycin, a macrolide antibiotic with potent activity against Toxoplasma gondii. Antimicrob. Agents Chemother.32, 5:755-7.

Araujo, FG, Shepard, RM, Remington, JS, 1991: In vivo activity of the macrolide antibiotics azithromycin, roxithromycin and Spiramycin against Toxoplasma gondii. Eur. J. Clin. Microbiol. Infect. Dis.10, 6:519-24.

Briggs, GG, Freeman, RK, Yaffe, SJ, 2011: Drugs in Pregnancy and Lactation. $9^{\text {th }}$ edition. Philadelphia: Williams \& Wilkins.

Castro-Filice, LS, Barbosa, BF, Angeloni, M B, et al, 2014: Azithromycin is able to control Toxoplasma gondii infection in human villous explants. J. Transl. Med.12:132-5.

Chamberland, S, Kirst, HA, Current, WL, 1991: Comparative activity of macrolides against Toxoplasma gondii demonstrating utility of an in-vitro microassay. Antimictob. Agen. Chemot- her. 35, 5:903-9.

Chew, WK, Segarra, I, Ambu, S, Mak, JW, 2012: Significant reduction of brain cysts caused by Toxoplasma gondii after treatment with Spiramycincoadministered with Metronidazole in a mouse model of chronic toxoplasmosis. Antimicrob. Agents Chemother. 56, 4:1762-8.

Crouch, AA, Seow, WK, Whitman, LM, Thong, YH, 1990: Sensitivity in vitro of Giardia intestinalis to dyadic combinations of Azithromycin, doxycycline, mefloquine, tinidazole and furazolidone. Trans. R. Soc. Trop. Med. Hyg. 84, 2: 246-8.

Derouin, F, Almadany, R, Chau, F, Rouveix, B, Pocidalo, JJ, 1992: Synergistic activity of azithromycin \& pyrimethamine or sulfadiazine in acute experimental toxoplasmosis. Antimicrob. Agents Chemother. 36, 5:997-1001.

Djurković-Djaković, O, Milenkovic, V, Nikolic, A, Bobić, B, Grujić, J, 2002: Efficacy of atovaquone combined with clindamycin against murine infection with a cystogenic (Me49) strain of Toxoplasma gondii. J. Antimicrob. Chemother. 50, 6:981-7.

Dumas, JL, Chang, R, Mermillod, B, Piguef, PF, Comte, R, et al, 1994: Evaluation of the efficacy of prolonged administration of Azithromycin in a murine model of chronic toxoplasmosis. J. Antimicrob. Chemother. 34, 1:111-8.

Faucher, B, Moreau, J, Zaegel, O, Frank, J, Piarroux, R, 2011: Failure of conventional treatment with pyrimethamine and sulfadiazine for secondary prophylaxis of cerebral toxoplasmosis in a patient with AIDS. J. Antimicrob. Chemother. 66, 7:1654-6.

Giacometti, A, Cirioni, O, Barchiesi, F, Ancarani, F, Scalise, G, 2000:Activity of nitazoxanide alone and in combination with Azithromycin and rifabutin against Cryptosporidium parv$u m$ in cell culture. J. Antimicrob. Chemother. 45, 4:453-6.

Gladue, RP, Bright, GM, Isaacson, RE, Newborg, MF, 1989: In vitro and in vivo uptake of Azithromycin (CP-62,993) by phagocytic cells: possible mechanism of delivery and release at sites of infection. Antimicrob. Agen. Chemothoer. 33, 3:277-82.

Gruji'c, J, Djurkovi'c-Djakovi'c, O, Nikoli'c, A, Klun, I, et al, 2005: Effectiveness of Spiramycin in murine models of acute and chronictoxoplasmosis. Int. J. Antimicrob. Agents 25, 3: 226-30.

Hampton, MM, 2015: Congenital toxoplasmos- 
is: A review. Neonat.Netw.34, 5:274-8.

Hermes, G, Ajioka, JW, Kelly, KA, Mui, E, et al, 2008: Neurological and behavioral abnormalities, ventricular dilatation, altered cellular functions, inflammation, and neuronal injury in brains of mice due to common, persistent, parasitic infection. J. Neuro-inflam. 23, 5:48-52.

Huskinson-Mark, J, Araujo, FG, Remington, JS, 1991: Evaluation of the effect of drugs on the cyst form of Toxoplasma gondii. J. Infect. Dis. 164, 1:170-7.

Israelski, DM, Remington, JS, 1993: Toxoplasma gondii is an intracellular protozoan parasite: Toxoplasmosis in the non-AIDS immuno-compromised host. Curr. Clin. Top. Infect. Dis. 13: 322-56.

Konstantinovic, N, Guegan, H, Stäjner, T, Belaz, S, Robert-Gangneux, F, 2019: Treatment of toxoplasmosis: Current options and future perspectives. Food Waterbor. Parasitol. 15:e00036. Krolewiecki, A, Leon, S, Scott, P, Abraham, D, 2002: Activity of Azithromycin against Leishmania major in vitro and in vivo. Am. J. Trop. Med. Hyg. 67, 3:273-7.

Lode, H, Borner, K, Koeppe, P, Schaberg, T, 1996: Azithromycin*Review of key chemical, pharmacokineticand microbiological features. J. Antimicrob. Chemother. 37:S1-8.

Lopes, CD, Silva, NM, Ferro, EA, et al, 2009: Azithromycin reduces ocular infection during

\section{Explanation of figures}

Fig. 1: Brain tissue from infected non treated mice (G2) showed Toxoplasma cysts (arrows) (H \& E, scale bar 25um).

Fig. 2: Brain tissue from infected non treated mice(G2) showed multiple focal necrosis associated with glia cells infiltration (short arrow) and perivascular cuffing with mononuclear inflammatory cells (long arrow) H \& E, scale bar 25um)

Fig. 3: Brain tissue from mice infected and treated by Azithromycin for 3days (G3) showed shrunken, atrophy and necrosis of neurons (arrow). (H \& E, scale bar 25um).

Fig. 4: Brain tissue from mice infected and treated by Azithromycin for 3days (G3) showed neurofibrillary tangles (arrows). (H \& E, scale bar 25um)

Fig. 5: Brain tissue from mice infected and treated by Azithromycin for 3days (G3) showed intravascular permeation with mononuclear inflammatory cells associated with perivascular cuffing with mononuclear cells (arrows) (H \& E, scale bar 10um).

Fig. 6: Brain tissue from mice infected and treated by Azithromycin for 10 days (G4) showed necrosis of neurons (short arrow) and intracellular edema (long arrow) (H \& E, scale bar 25um).

Fig. 7: Brain tissue from mice infected and treated by Azithromycin for 10 days (G4) showed neuronophagia of degenerated neurons (arrow) (H \& E, scale bar 25um).

Fig. 8: Brain tissue from mice infected and treated by Azithromycin for 10 days (G4) showed proliferation of glia cells (diffuse gliosis) (arrow) (H \& E, scale bar 25um).

Fig. 9: Brain tissue from mice infected and treated by Spiramycin for 2 weeks (G5) showed congestion of some blood vessels (arrow) with perivascular edema and degenerated neurons. (H\&E stain, X200)

Fig. 10: Brain tissue from control non-infected mice (G1) showed normal histological structure (H \& E stain, X200) 

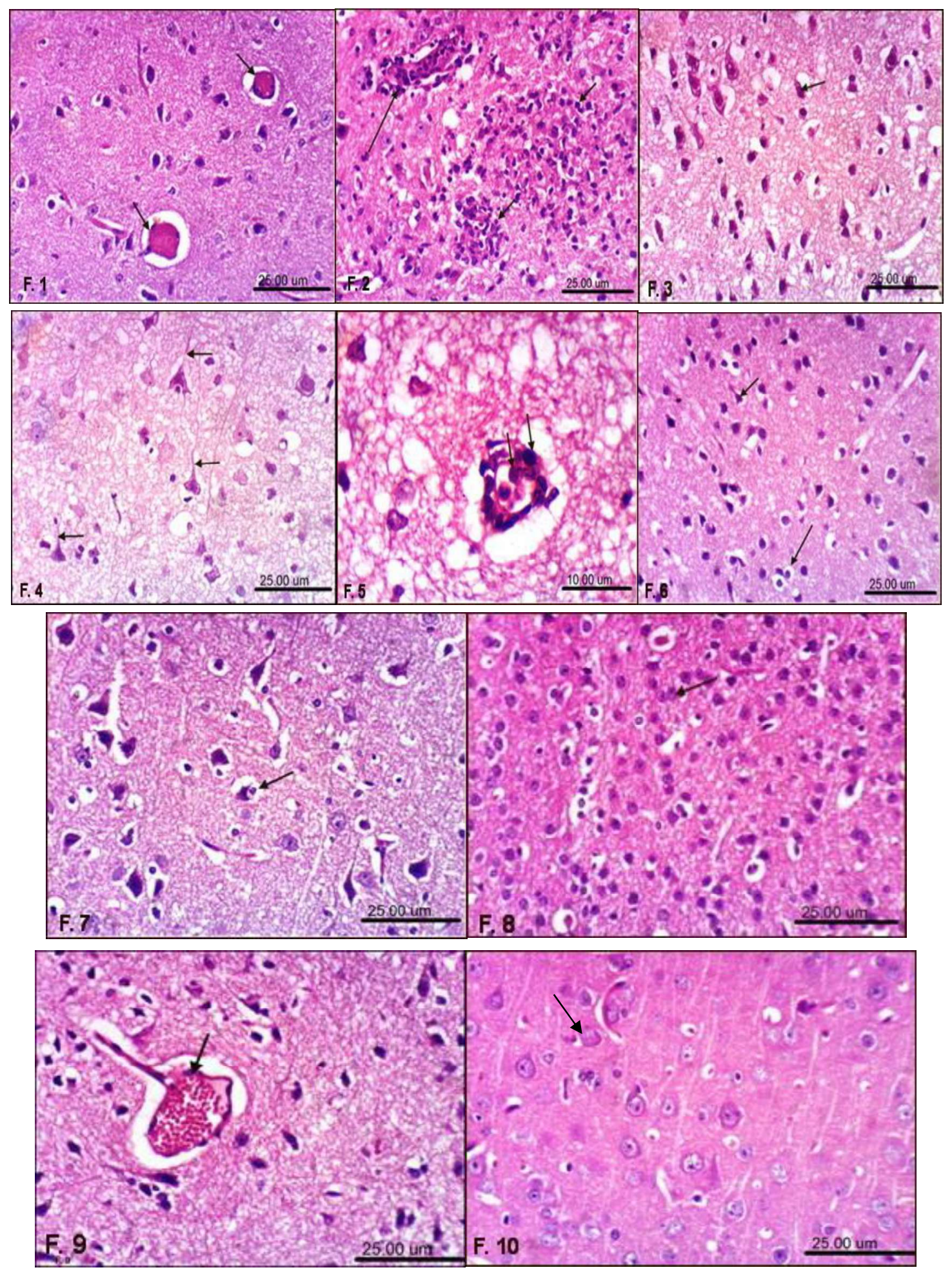